\title{
EFEK PEMANFAATAN PROGRAM PEMANTAUAN DAN PROMOSI PERTUMBUHAN TERHADAP STATUS GIZI BALITA DI KOTA CIREBON
}

\author{
Lia Nurcahyani'; Mohammad Hakimi² dan Toto Sudargo ${ }^{3}$ \\ ${ }^{1}$ Cirebon Midwifery Study Program in Health Polytechnic, Tasikmalaya \\ ${ }^{2}$ Graduate Program in Mother and Child Health-Reproductive Health, Gadjah Mada University \\ ${ }^{3}$ Graduate Program in Health and Nutrition, Gadjah Mada University
}

\section{ABSTRAK}

Kekurangan gizi merupakan kunci pokok persoalan kematian balita di dunia, yang salah satu penyebabnya yaitu kurangnya pemanfaatan program pemantauan dan promosi pertumbuhan. Kasus gizi kurang di Kota Cirebon melebihi angka provinsi dan nasional. Pada tahun 2008, partisipasi masyarakat dalam program pemantauan dan promosi pertumbuhan meningkat sebesar 19 persen dari tahun sebelumnya, tetapi kasus gizi kurang meningkat juga sebesar 0,23 persen. Penelitian bertujuan untuk mengkaji efek pemanfaatan program pemantauan dan promosi pertumbuhan terhadap status gizi balita. Jenis penelitian observasional dengan rancangan kohort retrospektif. Subjek penelitian sebanyak 246 balita usia 17-59 bulan beserta ibu yang memenuhi kriteria inklusi dan eksklusi. Pengambilan sampel menggunakan teknik three stage sampling dipadukan dengan purposive dan random sampling. Data yang digunakan berupa data primer dan sekunder dengan instrumen penelitian meliputi kuesioner, kartu menuju sehat, register gizi, laporan bulan penimbangan balita Kota Cirebon tahun 2008, timbangan injak digital, length board/ microtoise serta software antropometri WHO (2006). Pengolahan data menggunakan analisis univariabel, bivariabel dengan chi-square dan multivariabel dengan uji regresi logistik. Penelitian ini didukung oleh data kualitatif untuk mengetahui indikator input dan proses serta hambatan dalam pemanfaatan program pemantauan dan promosi pertumbuhan. Hasil penelitian menunjukkan bahwa pemanfaatan program pemantauan dan promosi pertumbuhan berpengaruh secara signifikan terhadap status gizi balita dengan $p<0,05$. Insidensi gizi kurang pada balita yang tidak memanfaatkan program pemantauan dan promosi pertumbuhan secara teratur 2,7 kali lebih besar dibandingkan balita yang memanfaatkan secara teratur setelah mempertimbangkan kontribusi pengetahuan dan sikap ibu serta umur balita. Indikator input, khususnya peran kader dalam proses program pemantauan dan promosi pertumbuhan tidak optimal. Hambatan pemanfaatan program meliputi faktor individu (kesehatan balita), faktor provider (alasan sosial), serta faktor komunitas (lokasi rumah secara geografis). Pemantauan pertumbuhan pada balita harus dilakukan setiap bulan, terutama pada umur 0-24 bulan. Keberhasilan program pemantauan dan promosi pertumbuhan dapat dicapai apabila mendapat dukungan secara komprehensif dari segi penerima pelayanan, pemberi pelayanan dan pembuat kebijakan.

Kata kunci: status gizi, pemantauan pertumbuhan,promosi pertumbuhan, balita

\section{EFFECT OF THE UTILIZATION OF GROWTH MONITORING AND PROMOTION PROGRAM TOWARD NUTRITIONAL STATUS OF UNDERFIVES AT CIREBON MUNICIPALITY}

\section{ABSTRACT}

Underweight is a key problem of mortality in underfives, which one of leading causes is lack of utilization of growth monitoring and growth promotion. Cases of underweight at Cirebon Municipality exceed the figure of provincial and national level. In 2008, community participation in growth monitoring and growth promotion program increased $19 \%$ from the previous year, however cases of underweight also increased to $0.23 \%$. The objective of the study is to investigate the effect of growth monitoring and promotion program utilization toward nutritional status of underfives. The study was observational one retrospective cohort design. Subject consisted of 246 underfives of 17-59 months and mothers that met the inclusion criteria. Sampling used three stages combined with purposive and random sampling techniques. Data consisted of primary and secondary obtained from questionnaire, growth chard, nutrition registry, monthly report of underfive weighing record at Cirebon Municipality 2008, digital scale, length board/ microtoise and WHO anthropometric software (2006). Data analysis were used univariate, bivariate with chi square test, and multivariate with logistic regression analysis. The study was supported with qualitative data obtained from observation and indepth interview with helped of 6 cadres and 2 nutrition staffs to identify input and process indicators and constraints in the utilization of growth monitoring and promotion program. The result showed that the utilization of growth monitoring and promotion program 
affected nutritional status of underfives significantly $(p<0.05)$. Incidence of underweight among underfives that did not utilize the program regularly was 2.7 times greater than in those utilizing the program regularly after considering the contribution of knowledge and attitude of mothers as well as age of underfives. Input indicators, especially role of cadres in the process of growth monitoring and promotion program at Cirebon Municipality, were not optimum. Constraints in program utilization consisted of individual (health reason), provider (social reason) and community (geographical reason) factors. In conclusion, monthly growth monitoring was prioritized on underfives for the first 24 month.Target of growth monitoring and promotion program might be achieved when there was comprehensive support from demand side (people that received the service), support side (service providers) and policy side (policy makers).

Keywords: nutritional status, growth monitoring, growth promotion, underfives

\section{PENDAHULUAN}

K ekurangan gizi adalah penyebab tidak langsung dari 3,5 juta kematian ibu dan anak serta berkontribusi sebesar 35 persen terhadap beban ganda penyakit balita secara global dan regional di dunia. ${ }^{1,2,3} \mathrm{Di}$ negara berkembang, kekurangan gizi berkontribusi sebesar 50-60 persen terhadap kematian balita. 4,5 Kekurangan gizi akan berdampak pada penurunan kualitas sumber daya manusia (SDM), yang lebih lanjut dapat berakibat pada kegagalan pertumbuhan fisik, perkembangan mental dan kecerdasan, menurunkan produktivitas, serta meningkatkan kesakitan dan kematian. 3,6

Di Indonesia, prevalensi gizi buruk dan kurang masing-masing sebesar 5,4 persen dan 13,0 persen. ${ }^{7}$ Kota Cirebon merupakan salah satu dari 9 kota yang ada di Provinsi Jawa Barat dengan kasus balita dengan gizi kurang terbanyak setelah Bogor, dengan angka yang melebihi angka provinsi dan nasional, yaitu sebanyak 13,19 persen, sedangkan prevalensi gizi buruk sebesar 1,57 persen.8,9

Salah satu penyebab terjadinya gizi kurang adalah kurangnya pemanfaatan pelayanan kesehatan. ${ }^{10,11} \quad$ Program yang direkomendasikan oleh WHO dan UNICEF untuk menurunkan gizi buruk dan kurang adalah program pemantauan dan promosi pertumbuhan/growth monitoring and promotion (GMP) program,4,12 yang dilaksanakan melalui posyandu. Program pemantauan dan promosi pertumbuhan sebagai skrining program untuk mencegah gizi kurang melalui deteksi dini gagal tumbuh terdiri dari dua terminologi yaitu pemantauan pertumbuhan dengan outcome penurunan gizi kurang/ buruk, kesakitan dan kematian balita, serta promosi pertumbuhan dengan outcome peningkatan perilaku/ pola asuh ibu (pengetahuan, sikap dan tindakan). ${ }^{13}$ Komponen dasar dalam program pemantauan dan promosi pertumbuhan terdiri dari input, proses, output, dan outcome. ${ }^{14}$

Berbagai literature review untuk meneliti efek program pemantauan dan promosi pertumbuhan sudah dilakukan, tetapi hasilnya masih bervariasi. Promosi pertumbuhan merupakan evidence yang tidak diragukan lagi, hal yang masih dipertanyakan apakah berat badan harus ditimbang setiap bulan dan dimasukan ke dalam kartu pertumbuhan. ${ }^{4}$ Hasil dari penelitian tersebut mengemukakan program pemantauan dan promosi pertumbuhan dapat meningkatkan status gizi balita dan dipengaruhi oleh intensitas pemanfaatan program. ${ }^{4}$ Penelitian lain mengemukakan hasil yang kontroversi, yaitu interval dalam melakukan penimbangan setiap bulan dirasakan terlalu sering. ${ }^{14}$ Penelitian lain mengemukakan program pemantauan pertumbuhan tidak berdampak pada status gizi terutama pada penurunan kasus gizi buruk pada balita, ${ }^{15}$ sehingga penelitian ilmiah mengenai program pemantauan dan promosi pertumbuhan, khususnya manfaat ataupun kerugiannya masih sangat kurang dan masih diperlukan. ${ }^{13}$

Pada tahun 2008, partisipasi masyarakat dalam program pemantauan dan promosi pertumbuhan di kota Cirebon meningkat sebesar 19 persen dari tahun sebelumnya, tetapi kasus gizi kurang meningkat juga sebesar 0,23 persen. ${ }^{16}$

Penelitian ini bertujuan untuk mengkaji efek pemanfaatan program pemantauan dan promosi pertumbuhan terhadap status gizi balita, serta mengetahui indikator input dan proses juga hambatan dalam pemanfaatan program, yang diharapkan dapat memberikan 
kontribusi terhadap upaya penurunan angka gizi kurang pada balita.

\section{METODE PENELITIAN}

Penelitian ini merupakan penelitian observasional, menggunakan rancangan kohort retrospektif dengan pendekatan kuantitatif dan kualitatif. Penelitian ini dilakukan di kota Cirebon, provinsi Jawa Barat pada bulan Januari 2010 dengan populasi penelitian yaitu seluruh balita beserta ibu di wilayah kota Cirebon.

Sampel diambil berdasarkan kriteria inklusi yaitu balita yang tercatat di laporan bulan penimbangan balita kota Cirebon tahun 2008 yang pada saat itu berusia 0-42 bulan dengan status gizi baik berdasarkan indikator BB/TB (pada saat penelitian balita berumur 17-59 bulan), balita dengan usia termuda (jika di keluarga terdapat balita lebih dari satu). Kriteria eksklusi yaitu balita dengan ibu yang bekerja, balita yang sudah tidak berdomisili di Kota Cirebon pada saat penelitian.
Teknik pengambilan sampel menggunakan metode three stage sampling dipadukan dengan purposive sampling dan random sampling. Besar sampel pada penelitian ini dihitung menggunakan rumus uji hipotesis untuk 2 propors ${ }^{17}$ dengan jumlah sebanyak 246 balita beserta ibu dari 6 posyandu. Data kualitiatif diperoleh melalui informan yaitu 6 orang kader serta 2 orang petugas gizi.

Sumber data meliputi data primer dan sekunder. Instrumen penelitian untuk memperoleh data primer meliputi kuesioner yang diadopsi dari CEBU RSUP dr. Sardjito UGM, timbangan injak digital, length board/ microtois serta software antropometri WHO (2006). ${ }^{18}$ Untuk data sekunder, instrumen yang dipakai meliputi kartu menuju sehat, register gizi serta laporan bulan penimbangan balita Kota Cirebon tahun 2008.

Analisis statistik yang digunakan dalam penelitian ini meliputi analisis univariabel, bivariabel, stratifikasi, interaksi serta multivariabel. Analisis data dilakukan untuk mendukung analisis kuantitatif.

Tabel 1

Distribusi Frekuensi Variabel Penelitian Efek Pemanfaatan Program Pemantauan dan Promosi Pertumbuhan terhadap Status Gizi Balita Di Kota Cirebon Tahun 2010

\begin{tabular}{lcc}
\hline \multicolumn{1}{c}{ Variabel } & $\mathrm{n}$ & $\%$ \\
\hline $\begin{array}{l}\text { Pemanfaatan program pemantauan dan promosi pertumbuhan } \\
\quad \text { Tidak teratur }\end{array}$ & 123 & 50,0 \\
$\quad$ Teratur & 123 & 50,0 \\
\hline $\begin{array}{l}\text { Penyakit infeksi } \\
\quad \text { Pernah }\end{array}$ & 111 & \\
$\quad$ Tidak pernah & 135 & 54,1 \\
\hline Umur balita & & \\
$\quad$ 0-24 bulan & 57 & 23,2 \\
25-36 bulan & 79 & 32,1 \\
37-59 bulan & 110 & 44,7 \\
\hline Pengetahuan ibu & & \\
$\quad$ Tidak baik & 110 & 44,7 \\
$\quad$ Baik & 136 & 55,3 \\
\hline Sikap ibu & & \\
$\quad$ Tidak mendukung & 108 & 43,9 \\
$\quad$ Mendukung & 138 & 56,1 \\
\hline Dukungan keluarga & & \\
Tidak mendukung & 110 & 44,7 \\
$\quad$ Mendukung & 136 & 55,3 \\
\hline
\end{tabular}


HASIL

Pada analisis univariabel ditemukan balita dengan gizi kurang berdasarkan indikator berat badan menurut tinggi badan (BB/TB) sebesar 17,1 persen, sedangkan berdasarkan indikator berat badan menurut umur (BB/U) sebesar 17,5 persen dan indikator tinggi badan menurut umur (TB/U) sebesar 19,5 persen. Pada analisis selanjutnya status gizi balita menggunakan indikator $\mathrm{BB} / \mathrm{TB}$.

Tabel 1 menunjukkan setengah dari seluruh balita yang menjadi sampel penelitian tidak memanfaatkan program pemantauan pertumbuhan secara teratur. Sebagian besar balita $(54,9 \%)$ tidak pernah mengalami penyakit infeksi dalam 2 minggu terakhir. Sebagian besar balita berumur 37-59 bulan. Persentase ibu yang memiliki pengetahuan tidak baik sebesar 44,7 persen dan 43,9 persen sikap ibu tidak mendukung terhadap perawatan dan pertumbuhan balita. Sedangkan sikap keluarga yang tidak mendukung terhadap pertumbuhan balita sebesar 44,7 persen.

Tabel 2 menunjukan, mayoritas ibu memiliki pengetahuan yang tidak baik $(82,9 \%)$ mengenai gizi dan KMS.

Tabel 2

Distribusi Frekuensi Variabel Pengetahuan Ibu tentang ASI Eksklusif, Gizi, Pemantauan Pertumbuhan dan KMS di Kota Cirebon Tahun 2010

\begin{tabular}{lrr}
\hline \multicolumn{1}{c}{ Variabel Pengetahuan Ibu } & $\mathrm{n}$ & $\%$ \\
\hline Pengetahuan tentang Asi Eksklusif & 76 & 30,9 \\
$\quad$ Tidak baik & 170 & 69,1 \\
$\quad$ Baik & 219 & 89,0 \\
\hline Pengetahuan tentang gizi & 27 & 11,0 \\
$\quad$ Tidak baik & & \\
$\quad$ Baik & 18 & 7,3 \\
\hline Pengetahuan tentang pemantauan pertumbuhan & 228 & 92,7 \\
$\quad$ Tidak baik & & \\
$\quad$ Baik & 204 & 82,9 \\
\hline Pengetahuan tentang KMS & 42 & 17,1 \\
$\quad$ Tidak baik & & \\
$\quad$ Baik
\end{tabular}

\section{Analisis Bivariabel}

Analisis bivariabel dilakukan menggunakan uji statistik chi square $\left(\mathrm{X}^{2}\right)$ dengan perhitungan relative risk (RR) serta tingkat kepercayaan $95 \%$.

\section{Analisis Pengaruh Variabel Bebas, Variabel Antara dan Variabel Luar terhadap Variabel Terikat}

Berdasarkan Tabel 3 dapat diketahui, pemanfaatan program pemantauan dan promosi pertumbuhan, pengetahuan dan sikap ibu, umur balita serta dukungan keluarga berpengaruh secara signifikan terhadap status gizi balita dengan $p<0,05$. Risiko terjadinya insidensi gizi kurang pada balita yang tidak memanfaatkan program pemantauan pertumbuhan secara teratur 2,5 kali lebih besar dibandingkan balita yang memanfaatkan secara teratur.

Risiko terjadinya insidensi gizi kurang pada balita dengan ibu yang memiliki pengetahuan tidak baik serta sikap yang tidak mendukung 2,5 kali lebih besar dibandingkan balita dengan ibu yang memiliki pengetahuan baik dan sikap mendukung. Risiko insidensi terjadinya gizi kurang pada balita yang berumur 0-24 bulan 2,1 kali lebih besar dibandingkan balita yang berumur 37-59 bulan, tetapi tidak terdapat perbedaan umur balita 25-36 dengan umur 3759 terhadap terjadinya gizi kurang pada balita. Risiko terjadinya insidensi gizi kurang pada balita dengan keluarga yang tidak mendukung 1,8 kali lebih besar dibandingkan balita dengan keluarga yang mendukung. Penyakit infeksi tidak berpengaruh terhadap status gizi balita. 
Tabel 3

Analisis Pengaruh Pemanfaatan Program Pemantauan dan Promosi Pertumbuhan, Pengetahuan dan Sikap ibu Penyakit Infeksi, Umur Balita dan Dukungan Keluarga terhadap Status Gizi Balita di Kota Cirebon Tahun 2010

\begin{tabular}{|c|c|c|c|c|c|c|}
\hline \multirow{3}{*}{ Variabel } & \multicolumn{4}{|c|}{ Status Gizi } & \multirow{3}{*}{$R R$} & \multirow{3}{*}{$95 \% \mathrm{Cl}$} \\
\hline & \multicolumn{2}{|c|}{ Kurang } & \multicolumn{2}{|c|}{ Baik } & & \\
\hline & $n$ & $\%$ & $\mathrm{n}$ & $\%$ & & \\
\hline \multicolumn{7}{|c|}{$\begin{array}{l}\text { Pemanfaatan program pemantauan } \\
\text { pertumbuhan }\end{array}$} \\
\hline Tidak teratur & 30 & 24,4 & 93 & 75,6 & $2,5^{*}$ & $1,34-4,65$ \\
\hline Teratur & 12 & 9,8 & 111 & 90,2 & & \\
\hline \multicolumn{7}{|l|}{ Pengetahuan ibu } \\
\hline Tidak baik & 28 & 25,7 & 81 & 74,3 & $2,5^{*}$ & $1,37-4,46$ \\
\hline Baik & 14 & 10,2 & 123 & 89,8 & & \\
\hline \multicolumn{7}{|l|}{ Sikap ibu } \\
\hline Tidak mendukung & 28 & 25,9 & 80 & 74,1 & $2,5^{*}$ & $1,41-4,61$ \\
\hline Mendukung & 14 & 10,1 & 122 & 89,9 & & \\
\hline \multicolumn{7}{|l|}{ Penyakit infeksi } \\
\hline Pernah & 23 & 20,7 & 88 & 79,3 & 1,5 & $0,84-2,56$ \\
\hline Tidak pernah & 19 & 14,1 & 116 & 85,9 & & \\
\hline \multicolumn{7}{|l|}{ Umur Balita } \\
\hline 0-24 bulan & 15 & 26,3 & 42 & 73,7 & $2,1^{*}$ & $1,07-3,97$ \\
\hline $25-36$ bulan & 13 & 16,5 & 66 & 83,5 & 1,3 & $0,64-2,59$ \\
\hline 37-59 bulan & 14 & 12,7 & 96 & 87,3 & & \\
\hline \multicolumn{7}{|l|}{ Dukungan keluarga } \\
\hline Tidak mendukung & 25 & 22.8 & 85 & 77,2 & 1.8 * & $1.03-3.19$ \\
\hline Mendukung & 17 & 12,5 & 119 & 87.5 & & \\
\hline
\end{tabular}

Keterangan : ${ }^{*}=$ Signifikan $(p<0,05), R R=$ Relatif Risk, $\mathrm{Cl}=$ Confidence Interval

\section{Analisis Pengaruh Variabel Bebas terhadap Variabel Antara}

Hasil uji statistik pada Tabel 4 dan Tabel 5 menunjukkan pemanfaatan program pemantauan pertumbuhan berpengaruh secara signifikan terhadap pengetahuan dan sikap ibu. lbu dengan pengetahuan tidak baik 1,4 kali lebih besar pada ibu yang tidak memanfaatkan program promosi pertumbuhan secara teratur dibanding ibu yang memanfaatkan program promosi pertumbuhan secara teratur. Ibu dengan sikap tidak mendukung 1,3 kali lebih besar pada ibu yang tidak memanfaatkan program promosi pertumbuhan secara teratur dibanding ibu yang memanfaatkan program promosi pertumbuhan secara teratur.

Tabel 4

Analisis Pengaruh Pemanfaatan Program Pemantauan dan Promosi Pertumbuhan terhadap Pengetahuan Ibu di Kota Cirebon Tahun 2010

\begin{tabular}{|c|c|c|c|c|c|c|}
\hline \multirow{3}{*}{ Variabel } & \multicolumn{4}{|c|}{ Pengetahuan ibu } & \multirow{3}{*}{$R R$} & \multirow{3}{*}{$95 \% \mathrm{Cl}$} \\
\hline & \multicolumn{2}{|c|}{ Tidak baik } & \multicolumn{2}{|c|}{ Baik } & & \\
\hline & $\mathrm{n}$ & $\%$ & $\mathrm{n}$ & $\%$ & & \\
\hline $\begin{array}{l}\text { Pemanfaatan program pemantauan dan } \\
\text { promosi pertumbuhan } \\
\text { Tidak teratur } \\
\text { Teratur }\end{array}$ & $\begin{array}{l}64 \\
46\end{array}$ & $\begin{array}{l}52,0 \\
37,4\end{array}$ & $\begin{array}{l}59 \\
77\end{array}$ & $\begin{array}{l}48,0 \\
62,6\end{array}$ & 1,4 * & $1,04-1,84$ \\
\hline
\end{tabular}


Tabel 5

Analisis Pengaruh Pemanfaatan Program Pemantauan dan Promosi Pertumbuhan terhadap Sikap lbu di Kota Cirebon Tahun 2010

\begin{tabular}{|c|c|c|c|c|c|c|}
\hline \multirow{3}{*}{ Variabel } & \multicolumn{4}{|c|}{ Sikap ibu } & \multirow{3}{*}{$R R$} & \multirow{3}{*}{$95 \% \mathrm{Cl}$} \\
\hline & \multicolumn{2}{|c|}{ Tidak mendukung } & \multicolumn{2}{|c|}{ Mendukung } & & \\
\hline & $\mathrm{n}$ & $\%$ & $\mathrm{n}$ & $\%$ & & \\
\hline \multicolumn{7}{|l|}{$\begin{array}{l}\text { Pemanfaatan program pemantauan dan } \\
\text { promosi pertumbuhan }\end{array}$} \\
\hline Tidak teratur & 62 & 50,4 & 60 & 49,6 & $1,3^{*}$ & $1,01-1,79$ \\
\hline Teratur & 46 & 38,2 & 77 & 62,6 & & \\
\hline
\end{tabular}

Keterangan : * $=$ Signifikan $(p<0,05)$

\section{Hubungan antara Variabel Luar terhadap Variabel Bebas}

Penyakit infeksi tidak berhubungan terhadap pemanfaatan program pemantauan dan promosi pertumbuhan ( $p$ value 0,370 ). Umur balita dan dukungan keluarga berhubungan dengan pemanfaatan program pemantauan dan promosi pertumbuhan ( $p$ value 0,001 dan 0,04).

\section{Analisis Stratifikasi}

Analisis stratifikasi dilakukan untuk memastikan apakah variabel luar merupakan variabel pengganggu/ tidak, menggunakan uji statistik Mantel Haenszel (M-H). Variabel luar dinyatakan sebagai variabel penggangu jika terdapat perbedaan crude estimate of effect (RR Crude) dengan adjusted estimate of effect (RR M-H) sebesar 10 atau 20 persen. ${ }^{19}$

Perbedaan nilai $R R$ crude dan $R R \mathrm{M}-\mathrm{H}$ pada Tabel 6 sebesar 12 persen, sedangkan pada Tabel 7 sebesar 4 persen, sehingga dapat disimpulkan bahwa umur balita dan dukungan keluarga bukan merupakan variabel pengganggu/ confounding.

Tabel 6

Analisis Stratifikasi Pemanfaatan Program Pemantauan dan Promosi Pertumbuhan terhadap Status Gizi Balita Berdasarkan Umur Balita di Kota Cirebon Tahun 2010

\begin{tabular}{|c|c|c|c|c|}
\hline \multirow[b]{2}{*}{ Umur Balita } & \multirow{2}{*}{$\begin{array}{l}\text { Pemanfaatan Program Pemantauan } \\
\text { dan Promosi Pertumbuhan }\end{array}$} & \multicolumn{2}{|c|}{ Status Gizi Balita } & \multirow{2}{*}{$\begin{array}{c}\mathrm{RR} \\
(95 \% \mathrm{Cl})\end{array}$} \\
\hline & & $\begin{array}{l}\text { Kurang } \\
\mathrm{n}(\%)\end{array}$ & $\begin{array}{c}\text { Baik } \\
\mathrm{n}(\%)\end{array}$ & \\
\hline \multirow[t]{2}{*}{$0-24$ bulan } & Tidak teratur & $11(61,1)$ & $7(38,8)$ & 5,9 \\
\hline & Teratur & $4(10,3)$ & $35(89,7)$ & $(2,19-16,17)$ \\
\hline \multirow[t]{2}{*}{$25-36$ bulan } & Tidak teratur & $9(24,3)$ & $28(75,6)$ & 2,5 \\
\hline & Teratur & $4(9,5)$ & $38(90,5)$ & $(0,85-7,6)$ \\
\hline \multirow[t]{2}{*}{$36-59$ bulan } & Tidak teratur & $10(14,7)$ & $58(85,3)$ & 1,5 \\
\hline & Teratur & $4(9,5)$ & $38(90,5)$ & $(0,51-4,6)$ \\
\hline $\begin{array}{l}\text { RR Crude } \\
R R M-H\end{array}$ & $\begin{array}{l}5 \% C l: 1,34-4,65) \\
5 \% C l: 1,59-5,18)\end{array}$ & & & \\
\hline
\end{tabular}


Tabel 7

Analisis Stratifikasi Pemanfaatan Program Pemantauan dan Promosi Pertumbuhan terhadap Status Gizi Balita Berdasarkan Dukungan Keluarga di Kota Cirebon Tahun 2010

\begin{tabular}{|c|c|c|c|c|}
\hline \multirow[b]{2}{*}{ Dukungan Keluarga } & \multirow{2}{*}{$\begin{array}{l}\text { Pemanfaatan Program } \\
\text { Pemantauan dan Promosi } \\
\text { Pertumbuhan }\end{array}$} & \multicolumn{2}{|c|}{ Status Gizi Balita } & \multirow{2}{*}{$\begin{array}{c}\text { RR } \\
(95 \% \text { Cl) }\end{array}$} \\
\hline & & $\begin{array}{c}\text { Kurang } \\
\mathrm{n}(\%)\end{array}$ & $\begin{array}{c}\text { Baik } \\
\text { n (\%) }\end{array}$ & \\
\hline \multirow[t]{2}{*}{ Tidak mendukung } & Tidak teratur & $20(31,7)$ & $43(68,3)$ & 2,9 \\
\hline & Teratur & $5(10,6)$ & $42(89,4)$ & $(1,20-7,37)$ \\
\hline \multirow[t]{2}{*}{ Mendukung } & Tidak teratur & $10(16,7)$ & $50(83,3)$ & 1,8 \\
\hline & Teratur & $7(9,2)$ & $69(90,8)$ & $(0,73-4,47)$ \\
\hline $\begin{array}{l}R R \text { Crude } \\
R R M-H\end{array}$ & $\begin{array}{l}: 1,34-4,65) \\
: 1,25-4,49)\end{array}$ & & & \\
\hline
\end{tabular}

\section{Analisis Interaksi}

Analisis interaksi dilakukan karena pada analisis stratifikasi terdapat perbedaan estimasi spesifik pada kedua strata. Berdasarkan hasil analisis interaksi, pemanfaatan program pemantauan dan promosi pertumbuhan tidak berinteraksi dengan dukungan keluarga tetapi berinteraksi dengan umur balita karena berhubungan secara signifikan dengan status gizi balita $(p<0,05)$, sehingga dapat disimpulkan variabel umur balita merupakan effect modifiers.

\section{Analisis Multivariabel}

Analisis multivariabel dilakukan untuk menganalisis hubungan antara variabel bebas dengan variabel terikat dengan mengontrol variabel luar yang pada analisis bivariabel berhubungan signifikan terhadap variabel terikat. ${ }^{20}$

Model 1 dibangun untuk menganalisis pengaruh pemanfaatan program pemantauan dan promosi pertumbuhan terhadap status gizi balita. Hasil analisis menunjukan pemanfatan program pemantauan dan promosi pertumbuhan berpengaruh secara praktis dan statistik terhadap status gizi balita $(R R=2,5$ dan 95\% Cl: 1,34 - 4,65). Model 1 memprediksi kejadian gizi kurang pada balita sebesar 3,4 persen.

Model 2 dibangun untuk menganalisis pengaruh pemanfaatan program pemantauan dan promosi pertumbuhan terhadap status gizi balita dengan mengikutsertakan variabel pengetahuan ibu. Pemanfaatan program pemantauan pertumbuhan secara tidak teratur dan pengetahuan ibu yang tidak baik memprediksi kejadian gizi kurang sebesar 6 persen.

Model 3 dibangun untuk menganalisis pengaruh pemanfaatan program pemantauan dan promosi pertumbuhan terhadap status gizi balita dengan mengikutsertakan variabel pengetahuan dan sikap ibu. Model 3 dapat memprediksi kejadian gizi kurang sebesar 7,5 persen.

Model 4 dibangun untuk menganalisis pengaruh pemanfaatan program pemantauan dan promosi pertumbuhan terhadap status gizi balita dengan mengikutsertakan variabel pengetahuan dan sikap ibu serta umur balita. Model 4 dapat memprediksi gizi kurang sebesar 9,7 persen.

Model 5 dibangun untuk menganalisis pengaruh pemanfaatan program pemantauan dan promosi pertumbuhan terhadap status gizi balita dengan mengikutsertakan variabel pengetahuan dan sikap ibu, umur balita serta dukungan keluarga. Model 5 dapat memprediksi kejadian gizi kurang pada balita sebesar 9,7 persen.

Analisis multivariabel dengan membangun beberapa model statistik, ditujukan untuk menemukan model yang paling sesuai dan hemat (fit and parsimonius) yang dipakai sebagai bahan pertimbangan dalam melakukan intervensi. Setelah melakukan likelihood ratio test (LR test) dan goodness of fit test, maka dipilih model 4 sebagai model yang fit dan parsimonius. 
Tabel 8

Analisis Pengaruh Pemanfaatan Program Pemantauan dan Promosi Pertumbuhan terhadap Status Gizi Balita dengan Mengontrol Pengetahuan dan Sikap lbu, Umur Balita, Dukungan Keluarga di Kota Cirebon Tahun 2010

\begin{tabular}{|c|c|c|c|c|c|}
\hline Variabel & $\begin{array}{c}\text { Model 1 } \\
\text { RR } \\
(95 \% \mathrm{Cl}) \\
\end{array}$ & $\begin{array}{c}\text { Model } 2 \\
\text { RR } \\
(95 \% \mathrm{Cl}) \\
\end{array}$ & $\begin{array}{c}\text { Model 3 } \\
\text { RR } \\
(95 \% \mathrm{Cl})\end{array}$ & $\begin{array}{c}\text { Model } 4 \\
\text { RR } \\
(95 \% \mathrm{Cl})\end{array}$ & $\begin{array}{c}\text { Model } 5 \\
\text { RR } \\
(95 \% \mathrm{Cl}) \\
\end{array}$ \\
\hline \multicolumn{6}{|c|}{$\begin{array}{l}\text { Pemanfaatan program } \\
\text { Pemantauan dan promosi } \\
\text { pertumbuhan }\end{array}$} \\
\hline $\begin{array}{l}\text { Tidak teratur } \\
\text { Teratur }\end{array}$ & $\begin{array}{c}2,5^{*} \\
(1,34-4,65) \\
1 \\
\end{array}$ & $\begin{array}{c}2,3^{*} \\
(1,20-4,20) \\
1 \\
\end{array}$ & $\begin{array}{c}2,1^{*} \\
(1,13-3,87) \\
1\end{array}$ & $\begin{array}{c}2,7^{*} \\
(1,43-4,91) \\
1\end{array}$ & $\begin{array}{c}2,7^{*} \\
(1,45-4,95) \\
1\end{array}$ \\
\hline $\begin{array}{l}\text { Pengetahuan ibu } \\
\text { Tidak baik } \\
\text { Baik }\end{array}$ & & $\begin{array}{c}2,2^{*} \\
(1,23-4,03) \\
1\end{array}$ & $\begin{array}{c}1,9^{*} \\
(1,01-3,51) \\
1\end{array}$ & $\begin{array}{c}1,8^{*} \\
(1,06-2,97) \\
1\end{array}$ & $\begin{array}{c}1,8^{*} \\
(1,05-3,09) \\
1\end{array}$ \\
\hline $\begin{array}{l}\text { Sikap ibu } \\
\text { Tidak mendukung } \\
\text { Mendukung }\end{array}$ & & & $\begin{array}{c}1,9 * \\
(1,06-3,73) \\
1\end{array}$ & $\begin{array}{c}1,8^{*} \\
(1,10-3,05) \\
1\end{array}$ & $\begin{array}{c}1,8^{*} \\
(1,09-3,17) \\
1\end{array}$ \\
\hline $\begin{array}{l}\text { Umur balita } \\
\qquad \begin{array}{l}0-24 \text { bulan } \\
25-36 \text { bulan } \\
37-59 \text { bulan }\end{array}\end{array}$ & & & & $\begin{array}{c}2,6^{*} \\
(1,48-4,67) \\
1,5 \\
(0,76-2,83) \\
1\end{array}$ & $\begin{array}{c}2,6^{*} \\
(1,50-4,67) \\
1,5 \\
(0,77-2,85) \\
1\end{array}$ \\
\hline $\begin{array}{l}\text { Dukungan keluarga } \\
\text { Tidak mendukung } \\
\text { Mendukung }\end{array}$ & & & & & $\begin{array}{c}0,9 \\
(0,59-1,52) \\
1\end{array}$ \\
\hline $\begin{array}{l}n \\
R^{2} \\
\text { Deviance }\end{array}$ & $\begin{array}{c}246 \\
0,034 \\
215,30\end{array}$ & $\begin{array}{c}246 \\
0,060 \\
207,36 \\
\end{array}$ & $\begin{array}{c}246 \\
0,075 \\
201,71 \\
\end{array}$ & $\begin{array}{c}246 \\
0,097 \\
192,54 \\
\end{array}$ & $\begin{array}{c}246 \\
0,097 \\
192,52\end{array}$ \\
\hline
\end{tabular}

\section{BAHASAN}

Balita dengan gizi kurang yang ditemukan dari 246 balita usia 17-59 bulan dalam penelitian ini, berdasarkan indikator $\mathrm{BB} / \mathrm{TB}$ $17,1 \%$. Insidensi gizi kurang lebih tinggi dibanding angka Provinsi Jawa Barat $(9 \%)$ serta angka nasional $(15 \%){ }^{7}$ Besarnya insidensi gizi kurang di atas 15 persen merupakan masalah kesehatan masyarakat yang sudah dianggap kritis. $^{7}$

Program pemantauan dan promosi pertumbuhan di Kota Cirebon ditujukan untuk menangani gizi kurang berdasarkan indikator $\mathrm{BB} / \mathrm{U}$ dan BB/TB, sedangkan balita yang pendek/ stunted tidak diintervensi. Indikator BB/U digunakan sebagai skrining awal dalam penentuan status gizi kurang melalui pengisian
KMS. Apabila ditemukan gagal tumbuh/ BGM, maka status gizi dikonfirmasi berdasarkan indikator BB/TB. Tindak lanjut dalam penanganan kasus gizi kurang ditentukan berdasarkan indikator BB/TB yang dapat menggambarkan status gizi saat ini. Indikator $\mathrm{BB} / \mathrm{TB}$ banyak digunakan untuk mengevaluasi program intervensi. Berdasarkan pertimbangan tersebut, maka penulis menggunakan indikator BB/TB dalam penelitian ini.

Berdasarkan Tabel 1 dapat diketahui sebagian balita tidak memanfaatkan program pemantauan dan promosi pertumbuhan secara teratur. Berdasarkan wawancara mendalam terhadap kader diperoleh informasi ibu yang tidak datang ke posyandu bukan hanya disebabkan oleh alasan kesehatan (balita sakit), tapi ada juga alasan sosial (ibu sibuk, ibu 
tersinggung jika anaknya dikatakan gizi kurang, anak menangis ketika ditimbang sehingga merasa kasihan dan malas untuk datang ke posyandu, anak sedang tidur atau sedang mengikuti PAUD), serta alasan jarak dari rumah ke posyandu. Hal ini harus menjadi perhatian bagi kader dan petugas kesehatan, terutama pada saat memberikan promosi pertumbuhan. Berdasarkan penelitian sebelumnya disebutkan, hambatan untuk mengakses pelayanan kesehatan dasar diantaranya alasan geografis meliputi jarak dan transportasi serta alasan sosial yang berhubungan dengan sikap dan tindakan dari petugas kesehatan. ${ }^{13,21}$

Hambatan-hambatan yang telah disebutkan di atas dapat dikelompokan menjadi hambatan yang berasal dari faktor individu (kesehatan balita), faktor provider (alasan sosial yang berasal dari interaksi antara ibu balita dan provider berupa perasaan tersinggung/ perasaan kasihan apabila balita menangis ketika ditimbang), serta faktor komunitas (lokasi rumah secara geografis).

Berdasarkan hasil analisis pada Tabel 3 dapat diketahui, pemanfaatan program pemantauan dan promosi pertumbuhan berpengaruh secara signifikan terhadap status gizi balita. Risiko terjadinya insidensi gizi kurang pada balita yang tidak memanfaatkan program pemantauan pertumbuhan secara teratur 2,5 kali lebih besar dibandingkan balita yang memanfaatkan secara teratur. Berdasarkan analisis interaksi dapat diketahui, umur balita merupakan effect modifiers, sehingga besarnya pengaruh pemanfaatan program pemantauan dan promosi pertumbuhan terhadap status gizi balita tergantung dari umur balita. Interpretasi hasil analisis stratifikasi dalam Tabel 6 , risiko terjadinya gizi kurang terjadi pada balita yang tidak memanfaatkan program secara teratur, paling besar terjadi pada balita dengan umur 0 24 bulan. Penimbangan setiap bulan difokuskan pada balita dengan umur 0-24 bulan, karena kehilangan 0,1-0,2 kg pada balita dengan umur $>24$ bulan mungkin tidak menggambarkan adanya gagal tumbuh, tetapi hanya fluktuasi yang normal. Walaupun demikian, untuk balita $>$ 24 bulan, kunjungan setiap bulan merupakan kesempatan untuk memberikan konseling kepada ibu/ pengasuh. ${ }^{22}$

Berdasarkan observasi pada saat pelaksanaan posyandu serta wawancara mendalam kepada kader dan petugas gizi diketahui bahwa program pemantauan dan promosi pertumbuhan di Kota Cirebon sudah berfungsi sebagai skrining program untuk mencegah gizi kurang melalui deteksi dini gagal tumbuh, walaupun upaya deteksi gagal tumbuh tersebut masih dilakukan oleh petugas gizi karena kader belum memahami konsep gagal tumbuh pada balita. Balita yang memanfaatkan program pemantauan dan promosi pertumbuhan secara teratur, maka akan diketahui pertumbuhannya setiap bulan, sehingga apabila terjadi gagal tumbuh, yaitu berat badan tidak naik minimal dalam 2 kali penimbangan maka akan terdeteksi secara dini. ${ }^{4}$

Kader belum memahami konsep gagal tumbuh disebabkan pengisian KMS, serta penentuan status gizi rata-rata dilakukan oleh petugas gizi, karena kader belum memahami fungsi KMS. Walaupun demikian, kader sudah mampu menimbang berat badan balita secara akurat, menggunakan timbangan injak digital dengan ketelitian $0,1 \mathrm{~kg}$. Pengukuran tinggi badan dilakukan oleh petugas gizi. Apabila ditemukan gagal tumbuh, tindakan selanjutnya, ibu akan diberitahu dan diberikan konseling gizi dan pertumbuhan, sehingga diharapkan dapat memberikan motivasi untuk merubah perilaku atau pola asuh ibu sehingga balita tidak akan mengalami gizi kurang. ${ }^{4}$

Upaya promosi pertumbuhan di kota Cirebon berpengaruh pada pengetahuan dan sikap ibu walaupun kekuatan hubungan yang didapatkan tidak terlalu besar. Kelompok ibu dengan pengetahuan yang tidak baik serta sikap yang tidak mendukung lebih banyak pada ibu yang tidak memanfaatkan program pemantauan dan promosi pertumbuhan secara teratur dibandingkan ibu yang memanfaatkan program secara teratur (Tabel 4 dan 5). Berdasarkan observasi serta wawancara mendalam terhadap petugas gizi dapat diketahui upaya promosi pertumbuhan sangat jarang dilakukan oleh kader, karena kader tidak mengerti kapan promosi pertumbuhan harus diberikan. Walaupun demikian, dari pernyataan kader mengenai sarana posyandu dapat disimpulkan sebenarnya ada keinginan kader untuk memberikan promosi pertumbuhan, tetapi karena terbatasnya pengetahuan dikarenakan kurangnya kader terlatih serta terbatasnya sarana posyandu terutama media gizi dan 
panduan gizi kurang bagi kader terkadang menjadi kendala bagi kader dalam memberikan promosi pertumbuhan.

Rata-rata posyandu sudah memiliki jumlah kader $>5$ orang. Tetapi jumlah kader terlatih (kader yang sudah mengikuti pelatihan) di setiap posyandu rata-rata $<5$ orang, salah satunya karena adanya pergantian kader. Jika mengikuti alur pelayanan pada program pemantauan dan promosi pertumbuhan, maka di setiap posyandu hendaknya memiliki 5 kader terlatih, sehingga tidak ada kader yang merangkap pelayanan. Pengetahuan kader akan meningkat tidak hanya dengan membaca tetapi harus melalui pelatihan. ${ }^{23}$ Pelatihan dan penyegaran kader yang berkesinambungan diperlukan karena sering terjadi pergantian kader dan pengetahuan kader yang masih terbatas. ${ }^{24}$ Pengaruh promosi pertumbuhan terhadap pengetahuan dan sikap ibu sangat dipengaruhi oleh kualitas kader/ petugas kesehatan. ${ }^{25}$

Follow up untuk kasus gizi kurang pada program pemantauan dan promosi pertumbuhan di Kota Cirebon sudah optimal. Berdasarkan hasil wawancara mendalam terhadap informan petugas gizi, apabila ditemukan kasus gizi kurang, maka tindakan yang dilakukan dengan memberikan promosi pertumbuhan serta memberikan makanan tambahan berupa biskuit, susu dan sebagainya. Walaupun dana operasional tahun sebelumnya kurang lancar, tetapi tahun ini akan diadakan kembali. Promosi pertumbuhan serta pemberian makanan tambahan lebih efektif dalam meningkatkan status gizi balita dibanding hanya diberi promosi pertumbuhan saja. ${ }^{26,27,28}$

Sistem program pemantauan dan promosi pertumbuhan diatur agar mudah dilaksanakan. Program pemantauan dan promosi pertumbuhan terdiri dari kegiatan pengukuran pertumbuhan/ berat anak yang teratur, pencatatan/ plotting berat badan ke dalam kartu pertumbuhan/ KMS, penilaian status gizi dan memberikan penyuluhan gizi serta melakukan tindakan/ follow up selanjutnya jika ditemukan pertumbuhan yang tidak normal. ${ }^{13}$ Alur kegiatan program pemantauan pertumbuhan di Kota Cirebon menggunakan sistem 5 meja, yaitu meja pendaftaran, penimbangan, pengisian KMS, penyuluhan/ promosi pertumbuhan, dan pelayanan kesehatan (follow up kasus). Berdasarkan hasil observasi, terdapat posyandu dengan alur kegiatan yang masih kurang tertib. Pada saat datang ke posyandu, ibu balita langsung ke meja penimbangan kemudian mengambil PMT penyuluhan dan langsung pulang tanpa melalui meja pendaftaran terlebih dahulu. Akibatnya terdapat sasaran balita yang datang, tapi tidak tercatat dan terlaporkan pertumbuhannya. Kurang tertibnya alur program pemantauan dan promosi pertumbuhan tersebut terjadi pada waktu sasaran balita datang secara bersamaan, sehingga tidak terpantau dengan baik. Selain itu, hal tersebut terjadi jika petugas gizi datang pada saat pelaksaanaan program telah dimulai, sehingga tidak bisa mengatur alur terlebih dahulu, padahal menurut petugas gizi hal itu sudah dibicarakan dengan kader setiap bulan. Hal itu mencerminkan peran kader yang tidak optimal.

Terbatasnya indikator input terutama peran kader yang tidak optimal yang ditemukan dalam penelitian ini kemungkinan karena terbatasnya sistem monitoring dan supervisi yang dilakukan oleh Dinas Kesehatan. Menurut informan petugas gizi, supervisi hanya dilakukan satu tahun sekali pada saat bulan penimbangan balita (setiap bulan Agustus), dan tidak dilakukan di setiap wilayah Puskesmas, tetapi hanya dilakukan di Puskesmas yang dijadikan sampel, misalnya Puskesmas dengan sasaran balita yang banyak. Sistem monitoring dan supervisi pada program pemantauan dan promosi pertumbuhan hendaknya dilakukan setiap bulan pada 6 bulan pertama sejak dilaksanakan program dan selanjutnya dilaksanakan setiap 3 bulan sekali. ${ }^{22}$ Sistem monitoring dan supervisi secara teratur adalah penting karena banyaknya pergantian kader serta masih rendahnya pengetahuan kader, ${ }^{24}$ serta penting dilakukan pada setiap Puskesmas, agar dapat meninjau secara langsung bagaimana proses program pemantauan dan promosi pertumbuhan, sehingga bisa dipakai sebagai bahan masukan dalam menentukan kebijakan selanjutnya.

Selain kurangnya pemanfaatan program pemantauan dan promosi pertumbuhan, penyebab gizi kurang pada balita yang ditemukan pada penelitian ini yaitu pengetahuan yang tidak baik dan sikap yang tidak mendukung dalam merawat balita yang lebih banyak ditemukan pada kelompok ibu yang tidak memanfaatkan program pemantauan dan promosi pertumbuhan secara teratur. 
Mayoritas ibu balita memiliki pengetahuan yang tidak baik mengenai gizi dan KMS (Tabel 2). Hal ini disebabkan jarang sekali kader menjelaskan pertumbuhan balita yang terdapat dalam KMS, karena kader pun kebanyakan tidak mengerti tentang KMS. Ibu dan kader penting untuk mengetahui dan mengerti tentang KMS, sebab dalam program pemantauan dan promosi pertumbuhan, KMS adalah instrumen yang tepat dalam menentukan kapan waktunya kader/ petugas kesehatan memberikan promosi pertumbuhan terhadap ibu balita. Melalui pengisian KMS, kader/ petugas kesehatan serta ibu balita dapat mengetahui pertumbuhan balita. Setelah pertumbuhan balita diketahui oleh petugas kesehatan/ kader dan ibu balita maka akan terjadi komunikasi diantara keduanya, sehingga ibu balita akan mengerti konsep pertumbuhan balita yang normal serta tidak normal. Apabila ibu mengetahui pertumbuhan balitanya tidak normal, diharapkan ibu termotivasi untuk merubah perilaku dalam merawat balita. 29,30 Walaupun demikian, mayoritas ibu memiliki pengetahuan baik mengenai ASI eksklusif dan pemantauan pertumbuhan. Penelitian sebelumnya mengemukakan, pengetahuan ibu yang tidak baik memberikan kontribusi terhadap terjadinya gizi kurang pada balita, ${ }^{31,32}$ sedangkan pola asuh/ sikap ibu dalam merawat dan memberi makan anak merupakan penyebab langsung terjadinya kurang gizi pada balita. ${ }^{11,33,34,35,36,37,38,39}$

Faktor penyebab lain yang menyebabkan gizi kurang pada penelitian ini yaitu umur balita dan dukungan keluarga. Risiko insidensi terjadinya gizi kurang pada balita yang berumur 0-24 bulan (dalam penelitian ini, definisi operasional 0-24 bulan sebenarnya balita dengan umur 17-24 bulan pada saat penelitian) 2,1 kali lebih besar dibandingkan balita yang berumur 37-59 bulan, tetapi tidak terdapat perbedaan umur balita 25-36 dengan umur 3759 terhadap terjadinya gizi kurang pada balita. Anak pada tahun kedua kehidupannya lebih sering mengalami gizi kurang. $40,41,42,43$ Dukungan keluarga akan berpengaruh terhadap perilaku kesehatan yang akan berpengaruh terhadap status gizi balita. ${ }^{44}$

Penelitian ini tidak membuktikan penyakit infeksi sebagai penyebab terjadinya gizi kurang pada balita. Manfaat lain dari program pemantauan dan promosi pertumbuhan yaitu meningkatkan kontak dengan petugas kesehatan. ${ }^{4}$ Jika balita mengalami penyakit infeksi, sedangkan ibu memanfaatkan program pemantauan pertumbuhan secara teratur, maka penyakit infeksi tersebut akan segera ditangani oleh petugas kesehatan. Selain itu, apabila pengetahuan dan sikap ibu mendukung dalam merawat balita sakit, maka penyakit infeksi tersebut tidak akan menyebabkan gizi kurang pada balita.

\section{SIMPULAN DAN SARAN}

\section{Simpulan}

1. Pemanfaatan program pemantauan dan promosi pertumbuhan secara tidak teratur terutama untuk balita 0-24 bulan serta pengetahuan dan sikap ibu yang tidak mendukung merupakan risiko terjadinya gizi kurang pada balita.

2. Indikator input, terutama peran kader dalam proses program pemantauan dan promosi pertumbuhan belum optimal.

3. Hambatan pemanfaatan program pemantauan dan promosi pertumbuhan meliputi faktor individu (alasan kesehatan), faktor provider (alasan sosial) serta faktor komunitas (lokasi rumah secara geografis).

\section{Saran}

1. Berdasarkan temuan tersebut maka pemantauan pertumbuhan secara teratur setiap bulan harus dilaksanakan terutama untuk balita dengan umur 0-24 bulan.

2. Perlu dilakukan strategi agar partisipasi masyarakat dalam program pemantauan dan promosi pertumbuhan lebih meningkat, diantaranya sweeping sasaran, serta memperbaiki mutu layanan sehingga tidak akan terjadi outcome yang tidak diharapkan dari ibu balita, misalnya kecemasan atau perasaan tersinggung. Indikator input (pengetahuan dan jumlah kader terlatih, sarana posyandu serta monitoring dan supervisi) dalam program pemantauan pertumbuhan harus ditingkatkan sehingga kader dapat berperan secara optimal, terutama dalam memberikan promosi pertumbuhan untuk meningkatkan pengetahuan dan sikap ibu.

3. Peneliti selanjutnya diharapkan meneliti tingkat kepuasan ibu setelah 
memanfaatkan program pemantauan dan promosi pertumbuhan.

\section{RUJUKAN}

1. Black, R., Allen, L., Bhutta, Z., Caulfield, L., de Onis, M., Ezzati, M., Mathers, C., Rivera, J. Maternal and child undernutrition: global and regional exposures and health consequences. The Lancet, 2008; 371(9608): 243-60.

2. Black, R., Moris, S., Bryce, J. Where and why are 10 million children dying every year? The Lancet, 2003 ; 361:2226-34.

3. Moris, S., Cogill, B., Uavy, R. Effective international action against undernutrition: why has it proven so difficult and what can be done to accelerate progress? Lancet, 2008 ; 371(9612): 608-21.

4. Asworth, A., Shrimpton, R., Jamil, K. Growth monitoring and promotion: review of evidence of impact. Maternal and Child Nutrition, 2008; 4(s1): 86-117.

5. Heikens, G. How can we improve the care of severely malnourished children in Africa? Plos Med, 2007 ; 4(2): 222-5.

6. Victoria, C., Adair, L., Fall, C., Hallal, P., Martorell, R., Ritcher, L., Sachdev, H. Maternal and child undernutrition: consequences for adult health and human capital. Lancet, 2008 ; 371(9609): 340-57.

7. Balitbang Depkes RI. Laporan nasional riset kesehatan dasar (RISKESDAS) 2007, Jakarta: Depkes Rl; 2008.

8. Dinkes Kota Cirebon. Profil Dinas Kesehatan Kota Cirebon tahun 2007, Cirebon ; 2007.

9. Dinkes Provinsi Jawa Barat. Profil Dinas Kesehatan Provinsi Jawa Barat tahun 2007, Jawa Barat; 2007.

10. UNICEF. Strategy for Improved nutrition of children and women in developing countries. New York: UNICEF; 1990.

11. WHO. Nutritional and poverty, Papers from the ACC/SCN 24 th Session Symposium, Kathmandu; 1997.

12. Mc.Donald, E., Bailie, R., Rumbold, A., Morris, P., Paterson, B. Preventing growth faltering among Australian indegenous children. Med J Aust, 2008; 188(8): 84-6.
13. Panpanich, R., Garner, P. Growth monitoring in children (review). Cochrane Database of Syst Rev 2009 ; (1).

14. Roberfroid, D., Kolsteren, P., Hoeree, T., Maire, B. Do growth monitoring and promotion programs answer the performance criteria of a screening program? a critical analysis based on a systematic review. Trop Med Int Health, 2005; 10(11):1121-33.

15. Hossain, S., Duffield, A., Taylor, A. An evaluation of the impact of a US\$60 million nutrition programme in Bangladesh. Health Policy Plan, 2005; 20(1): 35-40.

16. Dinkes Kota Cirebon Profil Dinas Kesehatan Kota Cirebon tahun 2008, Cirebon; 2008.

17. Lemeshow, S., Hosmer, D.W., Klar, J., Lwanga, S. Besar sampel dalam penelitian kesehatan. Alih bahasa Pramono, D. dan Kusnanto, H. Yogyakarta: Gadjah Mada University Press; 1997.

18. WHO WHO child growth standards: length /height-for-age, weight- for-age, weight-forlength, weight-for height and body mass index-for-age. methods and development. Geneva, Switzerland: WHO; 2006.

19. Kleinbaum, D., Sullivan, K., Barker, R. A Pocket guide to epidemiology.USA : Springer Science+Business Media, LLC; 2007.

20. Dawson,B \&Trapp,R.G. Basic and clinical biostatistic. Boston: Mc. Graw Hill Companies, Inc; 2004.

21. Oanh,T.T.M The Review of Barrier to Acces Helth Services for Groups in Vietnam: A Case Studi; 2009.

22. UNICEF. Experts consultation on growth monitoring and promotion strategis: program guidance for a way forward, New York, USA; 2008.

23. Roberfroid, D., Pelto, G., Kolsteren, P. Plot and see! maternal comprehension of growth charts worldwide. Trop Med Int Health, 2007; 12(9):1074-86.

24. Faber, M., Schoeman, S., Smuts. C.M., Adam, V., Ford, N. Evaluation of community based growth monitoring in rural district of the Eastern Cape and Kwazulu Natal Provinces of Sourth Africa. J Clin Nutr, 2009; 22(4): 185-94. 
25. Hurtado, E., Bixcul, A, Bustamante, R., Santizo, M. Evaluation of the growth monitoring and promotion component of the integrated care for children and women at the community level (AIEPI AINM-C); 2008.

26. Roy, S.K., Fuchs, G.J., Mahmud, Z., Ara, G., Islam, S., Shafique, S., Akter.S.S., Chakroborty, B. Intensive nutrition education with or without supplementary feeding Improves the nutritional status of moderately malnourished children in Bangladesh. J.Health Popul Nutr. 2005; 23(4) 320-30.

27. Sguassero, Y., de Onis, M., Carroli, G Community based supplementary feeding for promoting the growth of young children in developing countries. Cochrane Database Syst Rev , 2005; 19(4).

28. Tanner, C. Nutrition and food security early warning in Niger. New York: USAID; 2008.

29. Gragnolati, M., Bredenkamp, C., Gupta, M.D., Lee, Y.K., Shekar, M. ICDS and persistent undernutrition. Econ Polit Wkly, 2006; 41(12): 1193-202.

30. Joseph, E., Dowsehen, S., Izenberg, N. Public understanding of growth charts: a review literature. Patient Educ Coun, 2007; 65(3):288-95.

31. Ard El Insan Benevolent Association. Nutritional health care service for malnourished children under 5 years. Medical Aid for Palestinians; 2008.

32. Phengxay, M., Ali, M., Yagyu, F., Soulivanh, P., Kuroiwa, C., Ushijima. Risk factor for protein energy malnutrition in children under 5 years: study from Luangprabang province, Laos. Pediatr Int. 2007; 49(2): 260-5.

33. Ogunba, B. Maternal behavioral feeding practises and under five nutrion.J Appl Sci Res, 2006; 2(12):1132-36.

34. Pongou, R., Ezzati, M., Salamon, J. Household and community socioeconomic and environmental determinants of child nutritional status in Cameroon. BMC Public Health, 2006; 6 (98) :1-19.

35. Rajaram, S., Zottarelli, L., Sunil, T. Individual, household, programme and community effects on childhood malnutrition in rural India. Journal compilation, 2007; 3(2):129-40.

36. Reyes, H., Cuevas, R.P., Sandoval, A., Castillo, R., Santos, J., Douboval, S., Gonzalo. The family as a determinant of stunting in children living in conditions of extreme poverty. BMC Public Health, 2004; 4(57):1-10.

37. Smith, Hadad. What causes undernutrition in Sri Lanka? 2000. available in:

http://www.siteresources. worldbank.org. (diakses: 22 Agustus 2009).

38. Uthman, O. A multilevel analysis of a individual and community effect on chronic childhood malnutrition in rural Nigeria. J.Trop Pediatr, 2009; 55(2): 109 -15

39. Villers, A., Senekal, M. Determinants of growth failure in 12-24 month old children in a high density urban slum community in East London, South Africa.EJCN, 2002; 56(12):1231-41.

40. Alasfoor, D., Elsayed, M.K., Al Qasmi, A., Malankar, P., Sheth, M., Prakash, N Protein energy malnutrition among preschool children in Oman: result of national survey. Eastern Mediterranean Health, 2007; 13 (5): 1022-30.

41. Bloss, E., Wainaina, F., Bailey, R.C. Prevalence and predictors of underweight, stunting and wasting among children aged 5 and under in western Kenya. J. Trop Pediatr, 2004; 50 (5): 260-70.

42. Hasnain, S.F., Hashmi, S.K. Consanguity among the risk factors for underweight in children under five: a study from rural Sindh. J. Ayub Med Coll Abbottabad, 2009 ; 21 (3): 111-16.

43. Sapkota, V.P., Gurung, C.K. Prevalence and predictors of underweight, stunting and wasting in underfive children. J. Nepal Health Res Counc, 2009; 7 (15): 120-6.

44. Chaiken, M., Deconinck, Degefie, T. The promise of a community - based approach to managing severe malnutrions: a case study from Ethiopia. Food Nutr Bull, 2006; 27(2):95-104. 